\title{
Sağlık Profesyonellerinin Eğitiminde Görev Alan Eğiticilerin
}

Etik Sorumlulukları

Ethical Responsibilities of the Educators Taking Part in the

Education of Health Professionals

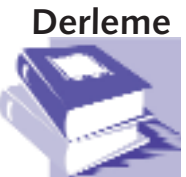

Review Article

\section{Şükrü Keleş ${ }^{1}$, Meral Demirören ${ }^{2}, S_{\text {Sevgi Turan }}^{3}$, iskender Sayek ${ }^{4}$}

DOI: $10.17942 /$ sted.730054

\section{Öz}

Giriş: Eğitim ve öğretim etiği, değerlerden köken alır. Sağlık profesyonellerinin eğitiminde görev alan eğiticilerin eğitim ve öğretim ortamında öne çıkan değerleri tanımaları ve bu doğrultuda eğitim faaliyetlerini yürütmeleri onların etik sorumlulukları arasında yer almaktadır. Temelde ahlaki bir duygu olan sorumluluk, eğiticilerin yaptıkları ya da yapmadıkları, kendilerinden yapmaları beklenen ödevler söz konusu olduğunda etik bir boyut kazanır. Bu çalışmada sağlık profesyonellerinin eğitiminde görev alan eğiticilerin etik sorumlulukları hakkında genel bir çerçeve çizmek amaçlanmaktadır.

Yöntem: Bu makale geleneksel derleme (narrative) çalışmasına dayalıdır. Bu bağlamda eğitim ve öğretim etiğinin değersel içerikli temel sorunları, ilgili literatür ışığında belirlenmiş ve yorumlanmıştır.

Bulgular: Geçtiğimiz on yılda eğitim sistemleri geliştirilirken mesleğin ya da toplumun değerlerinin merkeze alındığı, günümüzde ise özerkliğin yaygın olarak temel bir etik değer olarak kabul edilmesiyle birlikte, eğitim ortamında öğrenenin değerlerinin merkeze alındığı dikkati çekmektedir.

Sonuç: Eğitimde hangi değerlere öncelik verileceği ve benimseneceği, eğitim sisteminin hedef ve amaçları, toplumun nasıl bireyler yetiştirmek istediğiyle yakından ilgilidir. Günümüzde sağlık profesyonellerinin eğitiminde görev alan eğiticilerden, eğitim ve öğretim etiği çerçevesinde yer alan temel değerleri benimsemeleri ve eğitim ortamında yaşanan değersel sorunların farkına varabilmeleri beklenmektedir. Bu beklenti, eğiticilerin etik ilkeleri gözeterek davranmaları ve bu doğrultuda eğitici sorumluluklarını yerine getirmeleri, hatta kendilerini sorumlu hissetmeleri ile olanaklıdır.

Anahtar sözcükler: Eğitim ve öğretim etiği, Etik eğitimi, Sağlık profesyonelleri, Tıp eğiticileri, Etik sorumluluk
Geliş/Received : 03.04.2020

Kabul/Accepted : 01.09.2020

\begin{abstract}
Background: The concept of educational ethics is rooted in the values. So, knowing the values which are prominent in the educational environment and conducting educational activities accordingly are among the ethical responsibilities of the educators teaching health professionals. Responsibility, which is essentially a moral emotion, takes on an ethical aspect when it comes to the tasks that educators fulfil or do not fulfil and they are required to perform. This study aims at providing a general framework for the ethical responsibilities of the educators taking part in the education of health professionals.

Method: This study was based on a conventional
\end{abstract} narrative model. Within this context, the main value-related problems in education ethics were defined and interpreted in the light of related literature.

Findings: It is remarkable that while it was the profession itself or the social values that played a key role in the development of the educational systems in the last decade, today it is the values of the learner that is central to the educational setting as autonomy is widely considered as a basic ethical value.

Conclusion: The values to be prioritized and embraced in education is closely related to the aims and objectives of the education system and to the type of individuals the society wants to raise. Today, the educators taking part in the education of health professionals are expected to embrace the basic values that are present in educational ethics and to be aware of the value-related problems that may arise in the educational environment. This expectation can only be met when the educators take ethical principles into consideration while developing their behaviours, fulfil their responsibilities as educators and, in fact, feel responsible.

Key words: Educational ethics, Ethics education, Health professionals, Medical educators, Ethical responsibility

1 Dr. Öğr. Üyesi, Karadeniz Teknik Ü. Tıp Fak. Tıp Tarihi ve Etik AD, Trabzon (Orcid No: 0000-0003-2867-4608)

2 Doç. Dr.; Hacettepe Ü. Tıp Fak. Tıp Eğitimi ve Bilişimi AD, Ankara (Orcid No:0000-0001-7415-9602)

3 Prof. Dr.; Hacettepe Ü. Tıp Fak. Tıp Eğitimi ve Bilişimi AD, Ankara (Orcid No:0000-0001-9287-0641)

4 Prof. Dr.; Tıp Eğitimi Programlarını Değerlendirme ve Akreditasyon Derneği (Orcid No:0000-0001-5951-3511) 


\section{Giriş}

Akademik etik, akademi ile ilgili hem betimleyici hem de normatif etik sorunların niteliksel ve niceliksel açıdan araştırıldığı bir alandır (1).

Akademi ile ilgili olan hemen her konu, akademik etiğin çalışma alanına girmektedir. Bu çalışmada yükseköğretim kurumlarında sağlık profesyonellerinin eğitiminde görev alan eğiticilerin etik sorumluluklarına odaklanılmıştır. Bu sınırlandırmanın temel nedeni, eğitim ve öğretim etiği kavramının akademik etiğin önemli bir parçası olmasına rağmen araştırma ve yayın etiği ya da bilim etiği alanları kadar tartışmalarda öne çıkmaması, hatta gözardı edilmesidir.

Eğitim ve öğretim etiği, eğitim etkinliklerinin yürütülebildiği her ortamda eğitici ile öğrenen, eğitici ile eğitici, eğitici ile toplum ve ilgili diğer paydaşlar arasında ortaya çıkan değer sorunlarının saptanması ve bu sorunların çözümüne yönelik önerilerin sunulması biçiminde ifade edilebilir. $\mathrm{Bu}$ bağlamda, öne çıkan değerlerin neden önemli olduğuna, mesleğin oluşumuna ve gelişimine etkisini tartışmak esastır. Öte yandan, eğitim ve öğretim ortamlarında yaşanan değersel içerikli hangi sorunların eğitim ve öğretim etiği ile ilgili olduğunun belirlenmesi de eğitim ve öğretim etiğinin çalışma kapsamında yer almaktadır. Bu makalede eğitim öğretim etiğinin sağlık profesyonellerinin eğitimindeki yeri ve önemine ilişkin bir açıklama getirilmeye çalışılacaktır.

Sağlık alanında yaşanan değersel sorunlar, ileri teknolojilerin sağlık alanında kullanılmasının yaygınlaşması ve toplumun zaman içinde değişip dönüşmesi gibi nedenlerle çeşitlilik göstermektedir. Bu bağlamda, sağlık eğiticilerinin sağlık profesyonellerinin eğitiminde üstlendikleri sorumlulukların gözden geçirilmesine ihtiyaç duyulmaktadır. Sağlık alanında yaşanan gelişmeler ve toplumun beklentilerinin değişmesi akademideki tüm paydaşları yakından ilgilendirmektir. Bu nedenle, eğitim ve öğretim sürecindeki değersel sorunların saptanması ve etik açıdan kuşku duyulmayacak bir bakış açısıyla sorunlara yaklaşılması önemli görünmektedir.

Eğitim ve öğretim etiği denildiğinde değerler, gündelik yaşamdan ayrıştırılmayacak bir biçimde eğitim ortamının temel belirleyicileri arasında yer almaktadır. Eğitim ve öğretim etiğinin anlam içeriğinin oluşturulması değersel açıdan anlamlı bazı soruların sorulması ve bu soruların yanıtlanmaya çalışılması ile yakından ilişkilidir. Eğitim öğretim etiğinin özneleri, sağlık profesyonellerinin eğitiminde görev alan eğiticiler ve yöneticiler, öğrenenler, sağlık çalışanları, sağlık hizmetine başvuran/hasta ve hasta yakınları, sivil toplum kuruluşları, ulusal ve uluslararası bilim topluluğunun üyeleridir.

Yukarıda tanımlanan çerçeve kapsamında bu çalışmada aşağıdaki sorulara yanıt aranmaktadır:

Sorumluluk, hukuksal sorumluluk bağlamından farklı olarak etik ile ilişkili olan bir kavramdır (2). Bu bağlamda bir eğiticinin etik sorumlulukları nelerdir?

Ödev, belirli bir biçimde davranma gerekliliğidir; bir eylemin yapılmasının gerekli olduğu düşüncesidir (2). Bir tutumun ya da davranışın eğitim ve öğretim etiği açısından ödev olduğunu söylemenin anlamı nedir?

Bu soruların yanıtlanması sağlık profesyonellerinin eğitimi hakkında ve bu bağlamda etiğin eğitim ve öğretimdeki yeri ve önemi üzerine düşünmeyi zorunlu kılmaktadır. Bu konu ile ilgili farklı kurumlarda yürütülmekte olan çalışmalar, Türkiye'de Yüksek Öğretimde kabul edilen temel değerler çerçevesinde ele alınmıştır. Bu bağlamda sağlık profesyonellerinin eğitiminde görev alan eğiticilerin eğitim ve öğretim sürecindeki etik sorumluluklarının neler olabileceği tartışmaya açılmış ve öneriler sunulmuştur.

\section{Gereç ve Yöntem}

Sağlık profesyonellerinin eğitiminde hangi değerlerin öne çıktığını saptamak ve eğitim çalışmalarında neyin değer olduğunu belirlemek amacıyla, geleneksel derleme (narrative) yöntemi temel alınmıştır (3). Bu bağlamda eğitim ve öğretim etiği ile ilgili makaleler ve kuramsal kitaplar incelenmiş, bu tür kaynaklardan elde edilen bilgilere eleştirel bakış açısıyla yaklaşılmış ve yorumlanmıştır. Diğer yandan, eğitim ve öğretim etiğinin değersel içerikli temel sorunları, Yüksek Öğretim Kurumlarında varolan etik sorumluluklar dikkate alınarak incelenmiş ve ilgili paydaşlara konunun çerçevesine ilişkin öneriler sıralanmıştır. 


\section{Bulgular}

Etiğin eğitim ve öğretimdeki yeri ve önemi

Etik (ahlak felsefesi) değerlerden köken

almaktadır. Değerler, insana ait varlık yapısı

olanakları olarak kabul edilmektedir (4).

Değerlerin ne'liğine ilişkin sorulara yanıt arayan

etik, 'iyi ve kötü nedir?', 'doğru ve yanlış nedir?',

'insan için iyi olan nedir?' biçiminde

yapılandırımış sorulara yanıt arayan bir alandır

(2). Genel anlamda etik, insanın davranışlarını

konu edinir (5). Eğitimin insan davranışını

değiştirme amacında olması, eğitim etkinliklerinin

etik açıdan temellendirmesini de zorunlu

kılmaktadır.

Etiğin 'uygulamalı felsefe' alanına yönelmesiyle birlikte sağlık alanı başta olmak üzere uğraş alanlarında ortaya çıkan etik sorunlar üzerine ilgili literatürde verimli tartışmalar yürütüldüğü dikkati çekmektedir. Bu çalışmalarda, sağlık gibi

uygulamalı alanlarda gözlenen bu türden bir odaklanmanın eğitim ve öğretim etiğinde de olması gerektiği ve etiğin, eğitimin önemli bir bileşeni olduğu ifade edilmektedir $(6,7)$. Diğer yandan, eğitim ortamındaki etik sorumlulukların belirlenmesi, eğitimin niteliğini artırdığı gibi eğitimde hesap verilebilirliğe de katkı sunduğu kabul edilmektedir (8).

Günümüzde eğitim ve öğretim etiğinde yürütülen çalışmaların genel olarak eğitimdeki tutum ve davranışları iyi-kötü ya da doğru-yanlış gibi kavram çiftleri üzerinden değerlendirme çabası devam etmektedir. Ayrıca, eğitim ortamında izin verilen iyi ve doğru davranışların hangileri olduğu ya da bir eğiticinin etik değerlendirme sürecini nasıl yöneteceği cevaplandırılması gereken sorular arasındadır. Eğitim öğretim ortamındaki mevcut etik sorunların belirlenmesi, ilgili tarafların hassasiyetlerinin gözetilerek değerlendirilmesi, etik sorunlara yönelik çözüm önerilerinin geliştirilmesi ve olası eylemlere yönelik öneriler sunulması bakımından dikkate alınmalıdır.

\section{Sağlık profesyonelleri eğitiminin özellikleri}

Sağlık profesyonellerinin yetiştirilmesi görevini üstlenen kurum ve kişiler, toplum için 'nitelikli' meslek üyeleri yetiştirme sorumluluğunu da üstlenmiş durumdadır. Sağıık profesyonellerin sahip olması istenen niteliği belirleyen bu özellikler ulusal ve uluslararası birçok yetkinlik/yeterlik belgesinde tanımlanmıştır ve etik değerlere sahip olunması bu belgelerde uzlaşılan ortak noktalardan biri olarak dikkati çekmektedir (9-11).

Sağlık profesyonellerinin eğitimi, gerçekleştirildiği çok çeşitli öğrenme ortamları ve süreçleri nedeniyle örgütlenmesinde ve yürütülmesinde genel eğitime göre farklılık göstermektedir. Yaşantı ürünü, göreli olarak kalıcı davranış değişikliği ya da değişiklik potansiyeli olarak tanımlanan öğrenmeyi öğrenenin nitelikleri, eğiticinin nitelikleri, öğrenilecek konunun nitelikleri ve öğrenmenin gerçekleştiği ortam gibi çok sayıda faktör etkilemektedir (12). Sağlık profesyonelleri için tanımlanan koşullarda öğrenmeyi etkileyen faktörlerin daha karmaşık yapıda olduğu ifade edilebilir. Derslik, amfiler, küçük grup ortamları ve öğretim amaçlı tasarlanmış laboratuvarların yanında hastaların bulunduğu klinikler, ameliyathaneler ve laboratuvarlar gibi gerçek yaşam koşullarında eğitim yürütülmektedir. Öğrenme ortamları açısından yarattığı çeşitlikle birlikte bu eğitimin bir diğer farklılığı ise sağlık profesyonellerinin çeşitliğidir. Klinik ortamda hizmet, işin niteliğine göre değişen özellikte sağlık ekipleri ile yürütülmektedir. Bu sebeple eğitim, sağlıklı bireyler ve hastalar, sağlık profesyonelleri ve çalışanları, eğiticiler ve öğrenenlerin yer aldığı, gerçek yaşam koşullarında hizmetin devam ettiği karmaşık öğrenme ortamında verilebilmektedir.

Bu ortamda öğretime rehberlik etme görevini üstlenen eğiticilerin önemli rolü bulunmaktadır. Harden ve Crosby (2000), tıp eğiticisin rollerini 'yönlendirme', 'rol model olma', 'bilgi sağlama', 'kaynak geliştirme', 'planlama ve değerlendirme' ana eksenini içeren 12 başlıkta tanımlamaktadır (13). Hızla değişen bilgi ve teknoloji, yeni eğitici rollerinin tanımlanmasına yönelik tartışmaları da beraberinde getirmiştir. Yeni tartışmalar ile tanımlanan rollerde teknoloji kullanımının ve uygulamasının yanısıra, 'içeriğin yönetimi' ile ilgili değişiklikler öngörülmekle birlikte, klinik rol modellik ve koçluğun önemli olduğu vurgusunun devam ettiği de dikkati çekmektedir (14).

Günümüzde eğiticinin rolü geleneksel olarak bilgi aktarımından öğrenmeyi yönlendirmeye doğru dönüşmektedir. Hizmet sunmanın yanında eğitimin tüm aşamalarında eğiticinin etik ilkelere uygun davranması ve örnek olması 
gerekmektedir. Etiğin her bireyin özel ve profesyonel yaşamına yön vermesi gereken bir değerler topluluğu olduğu düşünüldüğünde, "etik eğitici kimdir?" sorusunun yanıtlanması önemli görünmektedir. Aydın, etik eğiticiyi, her şeyden önce, "adalet, saygı, güvenilirlik, dürüstlük ve nezaket gibi temel erdemleri, öğrenciyle olan her etkileşiminde ortaya koyan etik bir kişi" olarak tanımlamaktadır $(15,16)$. Yazarın aynı çalışmalarında eğiticinin uymakla yükümlü olduğu etik kuralların eğiticinin görevlerini, sorumluluklarını, yaklaşımını, bakış açısını yansıtması ve tüm bunların üzerinde adalet değerini içermesinin gerekli olduğu belirtilmektedir. İyinin ve doğrunun ne olduğu ve insanın bu iyiyi ve doğruyu ayırt etme ve davranışlarını buna göre yönlendirme çabalarının eğitimden bağımsız düşünülemeyeceğinin de altı çizilmektedir $(15,16)$.

Öğretim ve etiğin ortaklaşan yönleri bulunmaktadır. Her öğrenenin potansiyelini en üst düzeyde geliştirilebilmesi istenilir bir durumdur. Bu bağlamda öğretimin düzenlenmesini gerektiren "iyi öğretim", öğrenenlerin en iyiyi elde etmesi için ne yapılması gerektiği konusunda etik açıdan analitik bir karar vermeyi de içermektedir. Sağlık profesyonellerinin eğitiminde bu karmaşık yapı ve süreçlerin anlaşılması için öğrenme ve öğretimin açıklanmasına yönelik geliştirilmiş çok sayıda kuramın yol gösterici olduğu ifade edilebilir. Bu nedenle aşağıda öğrenme ve öğretimin açılanmasına katkı sağladığı düşünülen kuramlar kısaca açıklanmıştır.

\section{Ortamında öğrenme}

Ortamında öğrenme kuramı, geleneksel olarak deneyim kazanmış birini izleyerek öğrenmeyi "uygulama ve öğrenme toplulukları"na uyarlamaktadır. Bu kuramda öğrenenlerin gerçek etkinlikler ve sosyal etkileşimler aracılığıyla gerçek uygulamalarda kültürlenmesinin olanaklı olduğu iddia edilmektedir. Son konusu kuramın savunucuları, öğrenmeyi bireysel deneyimin içselleştirilmesi sürecinden öte sosyal deneyimin ayrılmaz ve bütünleyici bir parçası olarak görmektedir (17). Öğrenenlerin uygulama topluluklarına katılması ve profesyonel uygulamalarda yetkinleşebilmesi için sosyokültürel uygulamaların tümüne katılımı önemlidir. Böylece, kültürel değerler ve normlar öğrenilerek topluluğun gerçek bir üyesi konumuna gelmek olanak dahilindedir. Kuramın temel kavramlarından biri "Onaylanan Çevresel Katılım"dır. Onaylanan çevresel katılım, topluluğa yeni girenlerin çekirdek topluluk üyelerinden topluluğun değerlerini, kimliğini, becerilerini onaylanarak merkeze yanaştığı süreç biçiminde açıklanmaktadır (18). Ortamında öğrenme sürecinde görev ve olayları yansıtan içerik; içeriği kazanan, kullanabilen ve bu içeriğin yöneticisi olan kişiye ait ortam; durum, değerler ve inançları içeren bağlam; öğrenenin bir grup ile işbirliği içinde duruma ilişkin anlamı tartışacakları ve oluşturacakları topluluk; öğrenenin gerçek yaşamın içinde problemleri uzmanlar ile birlikte çalışacakları süreç, yani katılım yer almaktadır (19).

\section{Sosyal-bilişsel öğrenme}

Bandura'ya göre, birçok insan davranışı modeli gözlemleme yoluyla öğrenilir (20). Bu kurama göre insanlar yalnızca deneme-yanılma ile değil, başkalarının davranışlarını gözleyerek de öğrenirler. Gözleyerek öğrenme, yalnızca bir kişinin diğer kişilerin etkinliklerini basit bir biçimde taklit etmesi değil, çevredeki olayların bilişsel olarak işlenmesi ile kazanılan bilgidir.

Öğrenmenin etkili bir biçimde gerçekleşmesi, öğrenenin model aldığı kişide gözlemlediği davranışı taklit edebilme yeteneğine bağlıdır. Modelin davranış sonunda aldığı ödül ya da ceza gözlemleyenin o davranışı taklit edip etmemesini etkilemektedir. Model ve gözlemcinin özellikleri öğrenmeyi etkileyen önemli faktörler arasında yer almaktadır. Modelin özellikleri gözlemcinin ilgisini etkilemekte ve davranışın taklit edilebilirliğini önemli ölçüde belirlemektedir. Gözlemcinin sembolleştirme, öngörü, dolaylı öğrenme, özdüzenleme ve öz-yeterlik kapasitelerinin önemli bir yere sahip olduğu ifade edilmektedir (21).

\section{Deneyimsel öğrenme}

Deneyimsel öğrenmenin temel vurgusu deneyimin bilgiye dönüştürülmesidir. Bu modelde bireylerin bilinçli olarak farkına varma ve deneyim dönüşümlerini birleştiren dört aşamalı döngüsel bir çerçevede öğrenme açıklanmaktadır; somut deneyim, yansıtıcı gözlem, soyut kavramsallaştırma ve etkin yaşantı. Öğrenme, bu dört öğrenme aşaması arasındaki yaratıcı gerginliğin çözümünden meydana gelmektedir. Bu süreçte deneyimleme, yansıtma, düşünme 
(kavramsallaştırma) ve yapma döngünün temel eylemleri arasında yer almaktadır (22). Bu süreçler boyunca, öğrenen hem bilgiyi hem de bireysel anlamı oluşturur. Profesyonel öğrenmenin bilimsel bilgi kadar uygun bir kimlik oluşturmayı da içerdiği kabul edilmektedir (23).

Refleksiyon (yansıtma), deneyimsel öğrenmenin önemli bir parçasıdır. Gelecekte yapılacakların belirlenmesinde kişinin kendisi ve konumu hakkında daha geniş anlayışa sahip olmasını sağlayan üstbilişsel süreçtir. Deneyimlerden öğrenmek için deneyimin incelemesi ve analiz edilmesi gerekmektedir. Refleksiyon, 'bir eylem devam ederken gerçekleşen eylemde refleksiyon', 'eylem sonlandıktan sonra geriye dönüp değerlendirme yapma' ve 'eylemler üzerine tekrar düşünmeyi içeren eylem üzerine refleksiyon' olarak ayrılmaktadır (23).

Sağlık profesyonelleri eğitiminde öğrenme ve öğretimin açıklanmasına yönelik geliştirilmiş kuramlar, eğitim sürecinin değerlendirilmesinde bir bakış açısı kazandırmaktadır. Etik alanında öne çıkan ödev etiği, erdem etiği ve yararcı etik gibi geleneksel etik kuramlar yanında vaka temelli etik, anlatısal etik ve feminist etik gibi görececi yaklaşımlar da meslek etiklerinin değer sorunlarının ele alınmasında birbirinden farklı bakış açıları sunmaktadır. Kimi normlar ve davranış kuralları geliştirmek konusunda hem eğitim hem de etik alanının bilgi birikimi, eğitim mesleğinin temel değerlerini ve etik ilkelerini oluşturmak amacıyla birarada düşünce üretebilmelidir.

\section{Eğitim ve öğretim etiği ile ilgili yapılan çalışmalar}

Sağlık alanında görev alan eğiticilerin etik sorumluluklarının belirlenmesine yönelik yapılan çalışmalarda yalnızca eğiticilere odaklanılmadığı dikkati çekmektedir ve akademik kurumların eğitim programlarında genel etik ilkeler geliştirmeye çabaladıkları görülmektedir. Örneğin, Kanada'da "Yüksek Öğretimde Öğretme ve Öğrenme Birliği" tarafından "Üniversite Eğitiminde Etik IIlkeler" geliştirilmiştir. Bu çalışma kapsamında yükseköğretimde aktif görev alan eğiticilerin etik yükümlülükleri; 1. İçerikte yeterlik, 2. Pedagojik yeterlik, 3. Duyarlı olunması gereken konularla açık, dürüst ve pozitif bir biçimde baş etme, 4. Öğrenenin gelişimine katkı sağlama, 5.
Eğiticilerin öğrenenlerle ilişkisinde pedagojik ve akademik odaklanma, 6. Gizlilik, 7. Çalışma arkadaşlarına saygı duyma, 8. Öğrenenleri öğretim hedefleriyle uyumlu, geçerli, açı ve adil değerlendirme, 9. Kurumun politikalarını, eğitimsel amaçlarını ve standartlarını bilme ve saygı duyma, olmak üzere dokuz başlık altında toplanmıştır (24). Bu ilkeler çerçevesinde öğrenenlerin yararının öncelendiği dikkati çekmektedir; bununla birlikte rolleri ya da yetki düzeylerinden bağımsız olarak yüksek öğretimdeki tüm öğretim elemanlarının bu ilkelere uymaları önerilmektedir (25).

Tıp eğiticilerinin etik sorumluluklarına yönelik yapılan çalışmalarda tıp eğiticilerinin öğretmen, yönetici, idareci, araştırmacı ve hekim olarak çeşitli rollerinin olduğu kabul edilmektedir. Söz konusu eğitici rolleri için 'bireye saygı', 'yarar sağlama' ve 'dağıtıcı adalet' olmak üzere üç temel etik ilke üzerinde ortaklaşabileceği ifade edilmektedir (26). Başka bir çalışmada ise Sawant (2017), tıp eğiticileri etiğinde iki düzeyin göz önünde bulundurulmasını önemli görmektedir (27). Birinci düzey, idari düzey olup üniversite ya da kurumların düzenlemelerine göre biçimlenen, tıp eğiticisinin yürüttüğü öğretim ve değerlendirme süreç ve işlemlerini kapsamaktadır. Diğeri ise, kişisel düzey olarak kabul edilmekte ve tıp eğiticisinin tutum ve davranışlarını içermektedir. Bu çalışmada tıp eğiticisinin öğrenenlerle etkileşimde saygıı, güvenilir ve dürüst olması, öğrenenlere nezaket göstermesi gibi ahlaki erdemlere sahip olmasının önemine değinilmektedir. Ayrıca, eğitim topluluğunun bir üyesi olarak kabul edilen tıp eğiticisinin medya ya da uygunsuz ilişkiler yoluyla öğrenenlerle fiziksel temastan ve iletişimden kaçınması; kasıtlı olarak öğrenenler arasında ayrımcllık yapmaması; farklılıklara saygı göstermesi; cinsiyet, ırk, din, dil ya da öğrenenlerin farklı intiyaçları ya da yeteneklerinden bağımsız olarak eşitliği savunması; her öğrenen ile özenli ve adil bir yaklaşımla ilgilenmesi; öğrenenlerin potansiyellerine ulaşmalarını sağlamak amacıyla onların gereksinimlerini anlama sorumluluğunu üstlenmesi gerektiği ifade edilmektedir. Tıp eğiticilerinin öğrenme, sağlık ya da güvenlik açısından zararlı olabilecek durumlardan öğrenenleri korumak için çaba göstermesi; öğrenme ve öğretme, sınıf yönetimi, öğrenen başarılarının ölçülmesi ve değerlendirilmesi, 
öğretim programlarının uygun bir biçimde yürütülmesi ile ilgili yüksek standartları sağlaması ve sürdürmesi de önerilmektedir. Tıp eğiticileri ile ilgili olarak, mesleki bilgi ve becerilerini sürekli mesleki gelişimlerinin bir parçası olarak güncel tutmalarının önemine dikkat çekilmekte ve onlardan öğretim uygulamalarına yönelik yapıcı geribildirimlere olumlu yanıt vermeleri ve gerektiğinde tavsiyeler almaları beklenmektedir.

Konu ile ilgili yapılan çalışmaların bir bölümünde ise, bazı eğitim kurumlarının eğiticileri için tanımladıkları mesleki yükümlülükleri ve etik kodları şeffaf bir biçimde kamuoyuna duyurdukları dikkati çekmektedir. Örneğin, Harvard Tıp Okulu (2019), eğiticileri için tanımladığı mesleki sorumluluklar kapsamında öğrenenlere önyargısız davranılması, öğrenenlerin soru sormalarının teşvik edilmesi, öğrenenlerle materyal-bilgi-öğretim etkinliklerinin paylaşılması, geribildirim verilmesi, çıkar çatışmalarının dikkate alınması, süpervizyon ve değerlendirme konuları yer almaktadır (28). Diğer bir tıp fakültesinin web sayfası üzerinden yayınladığı eğitici yükümlülüklerinde, tıp eğiticilerin birincil yükümlülügünün bir eğitim kurumunun "varolma nedeni" olan öğrenenlere yönelik olduğunu, diğer tüm yükümlülüklerinin ise ikincil olduğunu belirtilmektedir (29). Söz konusu fakültenin tıp eğiticisi için tanımladığı etik kuralların, tıp eğiticilerinin üstlendikleri öğretim sorumluluklarını vurguladığı ve özellikle öğrenenlerle, okuldaki diğer bireylerle, kurumla ve toplumla olan ilişkilerinde nasıl bir performans göstermelerinin uygun olduğu yönünde bir rehber işlevi gösterdiği de ifade edilmektedir.

İlgili literatürde etik davranan tıp eğiticilerinin yetiştirilmesinde başvurulacak stratejiler arasında kurumsal politika ve düzenlemelerin, teşvik ve ödüllerin, gerektiğinde yaptırımların, düzenli olarak eğiticilere yönelik öğrenenlerden geribildirim alınmasının önemi üzerinde de durulmaktadır (26). Diğer yandan, tıp eğiticisi ile asistan arasındaki ilişkide sınırların nasıl çizileceğini deneyimlerden yola çıkarak açıklamaya çalışan Mohamed ve arkadaşları (2005), öğretim üyeleri ve asistanlar arasında güç, gizlilik, fikir hakkı, rol değişimi ve iletişimden kaynaklanan etik sorunlara dikkat çekmişler ve bu türden sorunların kişisel ve mesleki anlamda asistanları etkileme ve eğitim ortamlarına zarar verme potansiyeline sahip olduğunu ortaya koymuşlardır (30).

Rosenkoetter ve Milstead (2010), 1983 yılında yayınlanan hemşirelik eğiticilerine yönelik etik kuralları hemşirelik uygulamaları ve eğitim alanındaki gelişmeleri dikkate alınarak yeniden değerlendirmişlerdir (31). Yazarlar tarafından hemşirelik eğiticisi, kişisel eylem ve hemşirelik eğitimi uygulamalarında yeterliğini korumak ve sürdürmek için sorumluluk üstlenen ve hesap verebilirliği dikkate alan bir profesyonel olarak tanımlamışlardır. Aynı yazarlar, profesyonel hemşirelik uygulamalarında öğrenenlerin yeterlik kazanmaları için öğrenmelerini kolaylaştırma ve yönlendirme; hastayı ve öğreneni diğer kişilerin yetersiz, yasadışı ya da etik dışı uygulamalarından koruma; akademik ve sağlık kurumlarındaki meslektaşlarının yanı sıra öğrenenler, hastalar ve aileleri ile ilgili konularda gizliliğe saygı göstermenin önemine dikkat çekerek hemşirelik eğiticisinden beklenen etik davranışları belirlemeye çalışmışlardır. Ayrıca, hemşirelik eğiticisinin araştırma, eğitim faaliyetleri ve hemşirelik uygulamalarında teknolojiyi uygun biçimde kullanması, kendisini sürekli geliştirmesi, akademik ve eğitim uygulamaları ile öğrenenlere, akademik topluluğa, mesleğe ve topluma karşı hesap verebilirliği göstermesine de vurgu yapılmıştır.

Boozaripour ve arkadaşları (2018), hemşirelik eğitimindeki etik değerleri İranlı hemşirelik öğrencileri ve eğitimcileri açısından incelemişler ve hemşirelik eğitiminde öne çıkan etik değerleri yedi temada tanımlamışlardır (32):

1. Insanlık onuru: Bu tema hastaya saygı duymak; öğrenenlere saygı göstermek ve onları onurlandırmak; eğiticilere ve meslektaşlara saygı göstermek alt temalarını içermektedir.

2. Yetkinlik geliştirme: Hemşirelik eğitiminde etikmanevi yeterlik, bilimsel-teknik yeterlik, kültüreldini yeterlik olmak üzere üç alanda yeterliğin önemli olduğu düşünülmektedir.

3. Yapıcı insan ilişkileri: Bu tema nezaket, güven, esneklik ve anlayışın insan ilişkilerindeki yeri ve önemine dikkat çekmektedir. 
4. Eğitimde adalet: Eğitimde adalet, farklı yetenek sahiplerine eşit fırsatlar sağlamak ve öğrenenlerin tümünü güçlendirmek için eşit çaba sarf etmek biçiminde tanımlanmaktadır.

5. Bilgelik: Bilgelik, bilginin, eleştirel düşünme becerisinin, yaratıcı problem çözmenin ve insancıllığın yardımıyla elde edilebilecek entelektüel gelişim hedeflerinden biri olarak değerli görülmektedir.

6. Mükemmellik arayışı/görüşü: Bu tema ile ilgili temel değerler arasında öngörü, yenilikçilik, çok yönlü gelişim ve mesleklerarası ilişkiler yer almaktadır.

7. Taahhüt ve hesap verebilirlik: İyi dinleyici olmak, problemleri çözmek ve eğitim programını uygulama taahhüdünün bu temayı temsil eden değerler arasında olduğu bildirilmektedir.

Bir başka çalışmada ise, rehabilitasyon eğiticilerinin öğretim sorumluluklarını yerine getirirken karşılaşabilecekleri etik konular incelenmiş ve saptanan sorunlar, öğrenenlerle ikili ilişkiler; öğrenen seçimi; öğrenen yeterliliğinin ölçülmesi; öğrenenlerin denetimi; öğrenen bilgileri hakkında gizlilik; eğiticinin yetkinliği; kültürle ilgili konular olmak üzere yedi başlık altında tanımlanmıştır. Bu sorunların ortaya konulmasının etik kuralların tanımlanmasına temel oluşturması açısından önemli olduğu düşünülmektedir (33).

Yapılan çalışmalarda eğitim ve öğretim etiği ile ilgili benimsenen değerler, evrensel kabul görebilecek etik ilkeler üzerine temellendirilmektedir. Diğer yandan, coğrafi bölgeler arasında varolan kültürel farklılıkların da yapılan çalışmalara yansıdığı dikkati çekmektedir. Geçmişten günümüze taşınan insani değerlerin korunarak eğitim öğretim faaliyetlerinin organize edilmeye çalışıldığı söylenebilir. Sağlık alanında görev alan eğiticilerin etik sorumluluklarının ve çağın gereksinimlerine cevap verebilecek bir biçimde mesleki ödevlerinin yeniden tanımlanması, eğitim alanında tartışıması gereken güncel sorunlar arasında yer almalıdır. Bir sonraki bölümde eğitim öğretim etiği açısından ülkemizdeki mevcut duruma ilişkin bir değerlendirme yapılmaktadır ve konu ile ilgili öneriler sunulmaktadır.

\section{Tartışma}

Türkiye'de Yüksek Öğretimde kabul edilen temel değerler

Türkiye'de "Yüksek Öğretim Kurumları Etik Davranış Illkeleri"nde beş temel değer tanımlanmıştır (34). Sağlık profesyonellerinin eğitiminde görev alan eğiticilerin etik sorumluluklarının da aşağıda ifade edilen bu beş temel değer üzerinde yapılandırılabileceği düşünülmektedir.

i) Akademik özgürlük ve özerklik: Akademik personelin bireysel olarak kendi özgür tercihlerini yapabilmesi, bu açıdan hiçbir dayatma ve baskı ile karşılaşmaması anlamını taşımaktadır. Akademik özerklik, akademi ve akademisyenlerin kurumsal yapı içinde bir üst otoriteye ve/veya dışarıdan gelen emir ve talimatlara bağlı olmaksızın, akademik ve bilimsel çalışma alanlarını ve yöntemlerini özgürce belirleyebilme ve uygulayabilme durumlarını ifade etmektedir.

ii) Akademik dürüstlük: Akademik topluluğun üyeleri arasındaki güven ve dürüstlüğe dayalı bağları güçlendiren, toplumun bilime ve bilim insanına güvenini sağlayan, akademik çevrede uyulması gereken etik ilke ve standartlara uygun davranılmasına vurgu yapmaktadır. Akademik dürüstlük, akademik standartları içtenlikle yerine getirmek ve her türlü akademik etkinlikte dürüst, açık ve sorumlu davranışların korunmasını da içermektedir.

iii) Sorumluluk ve hesap verebilirlik: Her türlü eğitsel, bilimsel ve akademik davranış ve faaliyet nedeniyle, kişisel ve mesleki sorumluluğun üstlenilmesi ve bu bağlamda üstlenilen görevlerin gerekli nitelikte ve yeterli sayıda yerine getirilmesi anlamına gelmektedir. Ayrıca, üniversitenin kurumsal kimliğinin ve itibarının zarara uğratılmaması, maddi kaynaklarının en verimli biçimde kullanılması, diğer kişi ve birimlerle uyumlu ve etkili biçimde çalışılmasını da kapsamaktadır.

\section{iv) Temel hakların korunması ve} güçlendirilmesi: Yükseköğretim kurumları, üyelerinin ve toplumun tüm bireylerinin temel insan haklarını korur ve destekler. Eğiticiler, eylemlerinin ve aldıkları kararların her zaman bu hakları güçlendirip desteklediğini garanti etmelidir. 
v) Başkalarına saygı: Yükseköğretim kurumları insanların farklılıklarına saygı duyar ve onlara değer verir, ayrımcılık ve taciz gibi olumsuz davranışlara izin vermez. Başkalarına saygı duymak ile kastedilen meslektaşlar, çalışanlar, öğrenenler, paydaşlar ve kurum dışı birimler ve şahıslara saygı ve nezaket çerçevesinde davranmak, ilişki içerisinde olunan tüm şahısların onuru ve ihtiyaçlarını gözetmektir.

\section{Sağlık profesyonellerinin eğitiminde görev alan eğiticilerin etik sorumluluklarına yönelik öneriler}

Sorumluluğun hukuksal sorumluluk bağlamından farklı olarak etik ile ilişkili olan bir kavram olduğu düşüncesinden hareketle, eğitim ortamlarında ilgili paydaşların etik sorumlulukları pek çok boyutta değerlendirilebilir. Uygulama alanında sorumluluk üstlenen bir eğiticiden mesleğin temel etik ilkelerine göre davranması beklenir, bu bakış açısıyla benimsenen tutum ve davranışlar desteklenir. Bu doğrultuda yapılan davranışlar sonucunda o meslek kişisinin ödevini uygun bir biçimde yerine getirdiği kabul edilebilir.

Eğiticilerin, öğretim sürecindeki sorumluluklarının ve ödevlerinin yanı sıra öğrenenlere, kendi mesleki alanlarına ve topluma karşı da etik sorumluklarının bulunduğu dikkate alınmalıdır. Sağlık profesyonellerinin eğitiminde görev alan eğiticilerin etik sorumluluklarına yönelik bir dizi sorumluluk önerilmektedir. Bu çalışmada eğiticilerin öğretim sürecindeki etik sorumluluklarına yönelik öneriler yukarıda özetlenen literatür çerçevesinde yapılan çalışmalar gözden geçirilerek yazarlar tarafından tartışılarak geliştirilmiştir. Aşağıda yer alan taslak öneriler, Türk Tabipler Birliği'nin (TTB) 15-16 Aralık 2018 tarihlerinde düzenlediği Etik Bildirgeler Çalıştayı'nda sunulmak amacıyla hazırlanmıştır (35).

\section{Eğiticilerin öğrenenlere yönelik etik sorumlulukları}

Sağlık profesyonellerinin eğitiminde görev alan eğiticiler;

\section{- Öğrenenlere uygulama olanağı sunmalı;}

öğrenenlere zamanında, açık ve temellendirilebilir geri bildirimlerde bulunmalı, öğrenme çıktılarını açık biçimde ifade etmeli ve bu doğrultuda öğrenenleri nesnel bir biçimde değerlendirmelidir.
- Mesleki istihdamı sağlamak amacıyla öğrenenlere uygun kariyer fırsatları için nesnel ve doğru rehberlik yapmalıdır.

- Kariyer fırsatlarını da içerecek biçimde, öğrenenlerin mesleki gelişimlerine katkı sağlayacak olanakları değerlendirmeleri konusunda, öğrenenlere uygun ve yeterli rehberlik hizmeti sağlamalıdır.

- Öğrenenlerin kişisel özelliklerine saygılı davranmalı, her bir öğrenenin özerkliğini, haysiyetini ve mahremiyetini korumalıdır.

- Değerleri, tutumları ve görüşleri farklı olan ögrenenlerin haklarına saygı duymalı ve kendilerini ifade etmelerine olanak yaratmalıdır.

- Tüm öğrenenlere ve öğrenme sürecine katkı sağlayanlara adil ve tarafsız bir eğitim hizmeti sunmalıdır.

- Ayrımcılıktan kaçınmalı ve bu doğrultuda iyi bir model olmalıdır.

- Öğrenenlerin biyopsikososyal ve öğrenme gereksinimlerinin farkında olmalı ve bu gereksinimlerinin karşılanmasına destek olacak ortamlar ve fırsatlar oluşturmalıdır.

- Öğrenenlerin öğrenme ve bilgiye ulaşma becerilerini geliştirerek, kendilerini geliştirmeleri ve gerçekleştirmelerinde teşvik edici ve cesaretlendirici olmalıdır.

- Öğrenenlerin mesleki kimliklerinin gelişimine destek olmalıdır.

- Öğrenenlerin öğrenme ortamlarında bağımsız düşünmeye teşvik etmelidir.

- Öğrenenleri istismar etmemeli, kişisel çıkarları için manipüle etmemeli ve onları yönlendirmemelidir.

- Öğrenenlerle ilişkilerinde profesyonel sınırları aşmamalı ve öğrenenlerin tümüne eşit uzaklıkta olmalıdır.

- Taciz, istismar ve şiddet uygulamamalıdır.

- Eğitim ortamında baskıcı, aşağılayıcı, rahatsız edici davranışları görmezlikten gelmemeli, 
onaylamamalı ve geçici çözümlerle sorunları geçiştirmemelidir.

- Öğrenenlerden gelen hediyeleri kabul etmemelidir.

- Ders materyallerini ve kaynaklarını öğrenenler ile paylaşmalıdır.

- Mesleki uygulamalarında ve öğrenme ortamlarında profesyonel davranışları ile öğrenenlere rol model olmalıdır.

\section{Eğiticilerin topluma karşı etik sorumlulukları} Sağlık profesyonellerinin eğitiminde görev alan eğiticiler;

- Öğrenme ortamlarında başvuranların, hastaların, ailelerin ve toplulukların sağlığını olumsuz etkileyebilecek durumların farkında olmalı ve bu etkilerin ortadan kaldırılması için sorumluluk üstlenmelidir.

- Mesleki uzmanlık alanı, yetkinlikleri ve yeterlikleri ile uyumlu ve uzmanlık alanına ait sınırların farkında olarak hizmet sunmalıdır.

- Bireylerin ve toplumun sağlığının korunmasına destek olmalıdır ve sağlığı etkileyen eğitim, kültür, ekonomi ve benzeri sosyal belirleyicilerin geliştirilmesine katkı sunmalıdır.

- Topluma karşı sosyal sorumluluğunun farkında olarak, eğitim ve öğretim ile ilgili tüm hazırlık, yürütme, değerlendirme ve yönetim süreçlerini şeffaflık ve hesap verebilirlik ilkeleri çerçevesinde sürdürmelidir.

\section{Eğiticilerin meslek alanlarına karşı etik sorumlulukları}

Sağlık profesyonellerinin eğitiminde görev alan eğiticiler;

- Mesleğin gelişimi ve korunması amacıyla eleştirel düşünme yaklaşımını desteklemeli ve kabul etmelidir.

- Uzmanlık alanı ve bu alanın öğrenilmesi ile ilgili yaptığı çalışmalarını, süreçlerini ve sonuçlarını paylaşarak mesleğin gelişmesine katkıda bulunmalıdır.
- Meslektaşlararası çıkar çatışmalarının farkında olmalı, çıkar çatışması durumlarında etik akıl yürütme sürecine uygun davranmalı ve çatışmaya taraf olan kişilerin değerlerini korumak için çaba göstermelidir.

- Mesleki sorumluluklarını yerine getirirken uygun standartları, bilimsel bilgi ve rehberleri kullanmalıdır.

- Mesleki uygulamalarını toplumun değişen yapısını dikkate alarak yürütmelidir.

- İleri teknolojilerin tıpta yaygın bir biçimde kullanılmaya başlamasının yol açabileceği değersel içerikli sorunların farkında olmalıdır.

- Uzmanlık alanı ile ilgili meslek örgütlerine üye olarak etkin katıım sağlamalıdır.

\section{Eğiticilerin öğretim sürecindeki etik sorumlulukları}

Sağlık profesyonellerinin eğitiminde görev alan eğiticiler;

- Alanında yetkin kişiler olarak, mesleki yetkinliklerini sürekli mesleki gelişim ile sürdürmeli ve geliştirmelidir.

- Eğitim programlarının planlama ve uygulama aşamalarında sosyal ve kültürel çeşitliliğe duyarlı olmalıdır.

- Çalışma alanlarıyla ilgili güncel bilimsel gelişmeler ve uygulamalar hakkında bilgi sahibi olmalı; mesleki standartların ve bilimsel bilginin geliştirilmesine katkıda bulunmalıdır.

- Eğitim programını tamamlayan öğrenenlerin kazanması beklenen yeterliklerin kazandırılmasına odaklanmalı, bu yeterliklerin kazandırımasında ve değerlendirilmesinde uygun öğretim ve ölçme yöntemlerini belirlemeli, özgün ve tutarlı eğitim programları hazırlanmasını desteklemeli ve uygulamalıdır.

- Öğrenme süreçlerinde bilimsel olarak doğru ve güncel materyaller hazırlamalı ve kullanmalıdır.

- Uygulanan eğitim programının sonuçlarının ve etkililiğinin değerlendirilmesi konularında 
çalışmalar yürütmeli ve bu doğrultuda hazırlanan programların devamlılığını sağlamalıdır.

- Öğrenenlerin üst düzey (analiz, sentez, değerlendirme) düşünme becerisini geliştirecek eğitim program ve materyalleri geliştirmelidir.

- Öğrenenleri destekleyecek olumlu ve güvenli öğrenme ortamları oluşturmalıdır.

- Öğrenme ortamında yaşanan değersel içerikli sorunları tanımalı ve bu sorunların çözümüne yönelik öneriler sunmalıdır.

- Eğitimde fırsat eşitliğini gözetmeli, eğitime erişim ve eğitimini sürdürmede dezavantajlı durumda bulunan öğrenenleri desteklemelidir.

- Ders planlarına ilkesel olarak bağlı kalmalı, dersi yürütme sorumluluğunu üstlenmeli, zorunlu durumlar dışında bir başka eğitimciye dersi devretmemelidir.

- Sağlık profesyonellerinin eğitiminin önemli bileşenleri arasında yer alan sağlıklı bireyler, sağlık kurumlarına başvuranlar, hastalar olduğunun farkında olarak, tüm öğrenme süreçlerinde bu grupların zarar görmemesi amacıyla eğitim ortamını düzenlemeli, onların haklarının korunması için en üst düzeyde çaba göstermeli ve bu kapsamda öğrenenlere örnek olmalıdır.

- Sağlık hizmetlerinin yürütülmesi ve araştırıması kadar eğitimin sürdürülmesinin bir ekip çalışması olduğunun farkında olmalı, tüm sağlık ekibinin bu süreçteki katkısını önemsemeli ve onların çalışma alanlarına saygı duymalıdır.

- Sağlık alanında hizmet, eğitim ve araştırmanın karşııılı etkileşim ile mümkün olduğunun farkında olmalı, bu alanların bütününde etik davranışlar sergilemelidir.

- Eğitim ortamında dürüstlüğü korumalı, bilimsel bilgi birikimini olduğundan eksik ya da fazla göstererek kimseyi yanıltmamalıdır.

Eğiticilerin öğrenenlere, topluma, meslek alanlarına ve öğretim sürecine yönelik etik sorumlulukların neler olabileceği yukarıda sıralanmıştır. Eğitimde hangi değerlere öncelik verileceği ve benimseneceği, eğitim sisteminin hedef ve amaçları ile ilgili olduğu kadar toplumun nasıl bireyler yetiştirmek istediğiyle yakından ilgili olduğu düşünülmektedir. Günümüzde sağlık profesyonellerinin eğitiminde görev alan eğiticilerden, hiç olmadığı kadar eğitim ve öğretim etiği çerçevesinde yer alan temel değerleri benimsemeleri ve eğitim ortamında yaşanan değersel sorunların farkına varabilmeleri beklenmektedir. Bu beklenti, eğiticilerin etik ilkeleri gözeterek davranmaları ve bu doğrultuda eğitici sorumluluklarını yerine getirmeleri ile karşılanabilir.

\section{Sonuçlar}

Eğitim ve öğretim etiği çalışmalarında eğitim ortamlarının önemli bir bir bileşeni etik değerlerdir. Eğitim ve öğretim etiğinin anlam içeriğinin oluşturulması değersel açıdan anlamlı bazı soruların sorulması ve yanıtlanmasıyla yakından ilişkilidir. Bu çalışmada, eğitici sorumluluğu kaçınılmaz olarak etik alanı ile bir arada düşünülmüştür. Diğer yandan, bir eğiticinin ödevini yerine getirdiğinin kabul edilmesi için ön koşul, o meslek üyesinden beklentilerin karşılanması ve etik açıdan kuşku duyulmayacak tutum ve davranışlar sergilemesidir.

Ülkemiz genelinde eğitim ve öğretim etiğine yönelik tüm paydaşlar tarafından kabul görecek etik ilkelerin belirlenmesine gereksinim olduğu açıktır. Etik ilkelerin anlam içeriklerinin uygulamada karşılık bulması, farklı disiplinlerin sahip olduğu bilgi birikimiyle konuya yaklaşması ile olanaklı olduğu düşünülmektedir.

Son olarak, sağlık profesyonellerinin eğitiminde sorumluluk üstlenen paydaşların katılımıyla eğitim ve öğretim etiğindeki önceliklerin ülke genelinde tartışmaya açılması önemli görünmektedir. Bu bağlamda sağlık alanında eğitim ve öğretim etiğine yönelik, i) Ulusal ve uluslararası ölçekte var olan ilkelerin incelenmesi ve raporlanması; ii) Üniversitelerin ve sivil toplum örgütlerinin katılımı ile konu hakkında yöntem tartışması ile başlanarak bir yol haritası belirlenmesi amacıyla çalıştaylar düzenlenmesi; iii) Eğitim ve öğretim etiği temel ilkelerinin belirlenmesi kadar uygulamaya aktarılmasının da önemi vurgulanarak, mezuniyet öncesi ve sonrasında eğitimine devam eden tıp öğrencilerinin yanı sıra eğiticilere ve yöneticilere ulaşabilecek niteliksel ve niceliksel araştırmalar planlanması önerilmektedir. 
Illetişim: Dr. Şükrü Keleş

E-posta: kelesukru@gmail.com

\section{Kaynaklar}

1. Corlett JA. The Role of Philosophy in Academic Ethics. J Acad Ethics. 2014; 12:1-14.

2. Oguz NY, Tepe H, Ornek Buken N, Kırımsoy Kucur D. Biyoetik Terimleri Sozlugu, Turkiye Felsefe Kurumu, Ankara. 2005.

3. Hemingway, P., \& Brereton, N. (2009). What is a systematic review? Accessed April 30, 2020 at http://www.whatisseries.co.uk/whatis/.

4. Kucuradi i. Insan ve Degerleri, Turkiye Felsefe Kurumu, Ankara. 2003.

5. Pieper A. Etik. Cẹv: Veysel Atayman ve Gonul Sezer. Ayrıntı Yayınları, İstanbul. 1999.

6. Reiser SJ. The ethics of learning and teaching medicine. Acad Med. 1994; 69(11):872-6.

7. Gülcan NY. Discussing the importance of teaching ethics in education. Procedia - Social and Behavioral Sciences. 2015; 174:2622 - 2625.

8. O'Neill $J$ and Bourke R. Educating teachers about a code of ethical conduct, Ethics and Education, 2010; 5(2):159-172.

9. CanMEDS. Accessed April 30, 2020 at http://canmeds.royalcollege.ca/guide

10. Tomorrow's Doctors (2009). General Medical Council. Accessed April 30, 2020 at http://www.ub.edu/medicina_unitateducaciomedica/ documentos/TomorrowsDoctors 2009.pdf.

11. Ulusal Çekirdek Eğitim Programı (UÇEP). Accessed April 30, 2020 at https://www.yok.gov.tr/kurumsal/idaribirimler/egitim-ogretim-dairesi/ulusal-cekirdekegitimi-programlari.

12. Senemoğlu, N. College of Education Students'Approaches to Learning and Study Skills Education and Science 2011;(36):160.

13. Harden, R. M., \& Crosby, J. R. The good teacher is more than a lecturer-The twelve roles of the teacher. Medical Teacher. 2000; 22:334- 347.

14. Simpson D, Marcdante K, Souza KH, Anderson A, Holmboe E. Job Roles of the 2025 Medical Educator. Journal of Graduate Medical Education. 2018; 10 (3): 243-246.

15. Aydın İ. Öğrenmenlik Meslek Etiği. Accessed April 30, 2020 at http://inayetaydin.blogspot.com/2011/09/ogretmenli k-meslek-etigi.html.

16. Aydın İ. Eğitim ve Öğretimde Etik. 9. Baskı Pegem Akademi Yayıncılık, 2018.

17. Lave, J., \& Wenger, E. Situated Learning: Legitimate Peripheral Participation. Cambridge: Cambridge University Press. 1991.

18. Sadideen $H$, Kneebone R. Practical skills teaching in contemporary surgical education: how can educational theory be applied to promote effective learning? The American Journal of Surgery. 2012; 204: 396-401.
19. Kılıç E. Durumlu Öğrenme Kuramının Eğitimdeki Yeri ve Önemi GÜ, Gazi Eğitim Fakültesi Dergisi. 2004; 24 (3): 307-320.

20. Bandura, A. Social learning theory. New York: General Learning Press. 1971.

21. Senemoğlu, N. Gelişim Öğrenme ve Öğretim Kuramdan Uygulamaya, Pegem Akademi, 21. Baskı, Ankara, 2012.

22. Kolb, D. A. Experiential Learning, Englewood Cliffs, NJ.: Prentice Hall. 1984.

23. Yardley S, Teunissen P.W. \& Dornan T. Experiential learning: AMEE Guide No. 63, Medical Teacher.2012; 34:2 e102-e115.

24. Murray, H., Gillese, E., Lennon, M., Mercel, P., Robinson, M. Ethical Principles for College and University Teaching. New Directions for Teaching and Learning. 1996; 66:57-63.

25. McGinn, M.K. Teaching and Researching Ethically: Guidance for Instructor-Researchers, Educational Developers, and Research Ethics Personnel. The Canadian Journal for the Scholarship of Teaching and Learning. 2018; 9(1): Article 2 Accessed April 30, 2020 at https://ir.lib.uwo.ca/cjsotl_rcacea/vol9/iss1/2.

26. Singh A. Ethics for Medical Educators: An Overview and Fallacies. Indian Journal of Psychological Medicine.2010; 32(2): 83-86.

27. Sawant, S.P. Ethics for Medical Educators. Anatomy \& Physiology: Current Research. 2017; 7:257.

28. Harvard Tıp Okulu. Eğitici ve Öğrencilerin Etik Sorumlulukları. Accessed April 30, 2020 at https://medstudenthandbook.hms.harvard.edu/401responsibilities-teachers-and-learners\#teachers.

29. East Ramon Magsaysay Üniversitesi, Memorial Tıp Merkezi. Accessed April 30, 2020 at https://uerm.edu.ph.

30. Mohamed, M., Punwani, M., Clay, M., Appelbaum, P. Protecting the Residency Training Environment: A Resident's Perspective on the Ethical Boundaries in the Faculty-Resident Relationship. Academic Psychiatry. 2005; 29:368-373.

31. Rosenkoetter, M. M. \& Milstead, J. A. A code of ethics for nurse educators: Revised. Nursing Ethics. 2010; 17(1):137-139.

32. Boozaripour, M., and Abbaszadeh A., Shahriari, M., Borhani, F. Ethical values in nurse education perceived by students and educators. Nursing Ethics. 2018; 25(2): 253-263.

33. Falvo D. R., Parker R. M. Ethics in Rehabilitation Education and Research. Rehabilitation Counseling Bulletin. 2000; 43:197-202, 214.

34. Yüksek Öğretim Kurumu (YÖK) (2014). Etik Davranış Illkeleri. Accessed April 30, 2020 at https://www.ankara.edu.tr/wpcontent/uploads/sites/6/2015/01/etik-davranışilkeleri.pdf.

35. Türk Tabipleri Birliği Etik Bildirgeler Çalıştayı, Accessed April 30, 2020 at https://www.ttb.org.tr/yazisma_goster.php?Guid=1a e6744e-f4ad-11e8-a887-6c865b380675. 